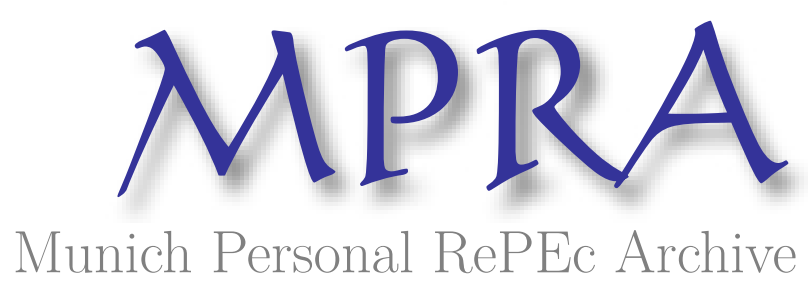

\title{
Determinants of homeownership in Malaysia
}

Tan, Teck Hong

16 June 2008

Online at https://mpra.ub.uni-muenchen.de/34909/

MPRA Paper No. 34909, posted 21 Nov 2011 09:03 UTC 


\title{
Determinants of Homeownership in Malaysia
}

\author{
Tan, Teck Hong
}

\section{waltertanth@gmail.com; walter tan@hotmail.com}

\begin{abstract}
The housing industry is crucial to the sustainable development in Malaysia. The efficiency and effectiveness of the housing delivery system requires housing provision for all. The housing industry, which had grown rapidly in the 1980 s encountered property oversupply recently. The majority of these units remain unsold for reasons beyond price factor, ranging from poor location to unattractive houses. The main objective of this paper is to tackle property oversupply in the country by examining a detailed knowledge of home owning determinants. Homeownership should be encouraged as positive externalities of homeownership can be found in many housing surveys. Homeownership is a complex issue that is the result of many determinants, including housing characteristics (house types and property types), employment and income trends, sociocultural and demographic descriptors. In addition to determinants, efforts needed to reduce regulatory barriers in the housing delivery system that can significantly increase the cost of producing houses. The government should make home financing more available and affordable by providing subsidies to low income families and creating incentives to save for homeownership. Efforts also needed to extend opportunities to enhance the affordability of homeownership by liberalizing rules and regulation of Employee Provident Fund (EPF) withdrawal.
\end{abstract}




\subsection{Introduction: Homeownership}

Owning a house is a major goal for every Malaysian. The efficiency and effectiveness of the housing delivery system has been identified as major social and economic objectives in Malaysia. However, there was a massive over constructing of housing in the country. The property overhang in the housing industry becomes the central concern to the government. The majority of these units remain unsold for reasons beyond price factor, ranging from poor location to unattractive houses with lack of adequate amenities and facilities. The housing delivery system requires a careful estimation of determinants of homeownership as different householders have different motivations of home owning.

\subsection{Literature Review}

What is the main reason for individuals to own their properties? Motivation has been important reason in the explanation of home ownership. According to Vroom (1964), individuals behaviors depend on the types of outcome expected. Individuals are motivated when they see a favorable combination of what is important to them and what they expect as a reward for their efforts and they behave accordingly. Outcome measures of homeownership to both homeowners and society can be found in many housing studies ranging from social to financial externalities.

\subsection{Neighborhood Stability}

A higher rate of homeownership is often thought to promote neighborhood stability. Using the U.S. Census of Population and Housing for 1980 and 1990, Rohe and Steward (1996) show that there is a positive relationship between homeownership and the length 
of tenure holding all the other factors constant, which suggesting that households normally buy their house units only if they are committed to remaining in a community for a long time as the transaction costs associated with buying and selling property are relatively high. They also support the hypothesis that changes in homeownership rates are positively and significantly affected by changes in property values. They argue that homeowners are more likely to invest in their properties maintenance and improvement at a higher standard.

Rossi and Weber (1996) and DiPasquale and Glaeser (1999) augment the work of Rohe and Steward by including other neighborhood stability indicators using the US General Social Survey, National Survey of Families and Households and the American National Election Studies. They both use local amenity investment which is defined as an investment in local public goods and social capital investment which is defined as a social link among citizens. The conceptual difference between these two investments is that the actions of local amenities investment improve the quality of the neighborhood whereas the actions of social capital investment improve the connection between householders and their neighbors. Overall, their results suggest that homeownership has the effects on both social capital and local amenity provision. Homeowners in U.S. know the name of their Representative; know the name of their local school board heard; vote in local election; and solve local problems; join more nonprofessional organizations; enjoy gardening and attend church more frequently than renters. These evidences suggest that housing is more than just bricks and mortar. It is the building block of community and the greater commitment that homeowner have toward their neighborhood might show 
clearly itself in greater socialization with neighbors, and volunteerism in the community. These activities have obvious caused positive externalities for the neighbors who can free ride on others efforts to make the community a better place to live.

\subsection{Improved Education Outcomes for the Children of Homeowners}

As neighborhood stability improves, it is possible that children education outcomes will improve and behavior problem will reduce as several researchers argue that the child will be exposed to a more stable school environment due to a better home environment in which a child lives.

Green and White (1997) develop probit estimation home owning models to analyze the relationship between teenagers' outcomes and homeownership and to examine whether children of homeowners stay in school longer than children of renters and whether they are less likely to have children themselves as teenagers using the Panel Study of Income Dynamics (PSID), the Public Use Microsample of the 1980 Census of Population and Housing (PUMS), and High School and Beyond (HSB). Results from the PSID suggest that home owning has an important effect on the probability of teenagers staying in school until age 17. Similar result is produced using PUMS data. The sample of HSB data set supports the hypothesis that home owning by parents is a statistically significant determinant of whether their children stay in school. The data also find that daughters of homeowners have much lower incidence of teenage pregnancy. 
Aaronson (2000) contribute to literature on children education outcomes by estimating more detailed specification of the homeownership effect. He argues the findings of Green and White (1997) on the benefits of homeownership are spurious because they do not study specific reason for why homeownership has a significant effect on children's success. It could be the role of neighborhood characteristics play a role in the effects of homeownership on children's outcomes. He shows that neighborhood residential stability enhances the positive effects of homeownership on high-school graduation, which suggests that some of the positive effects of homeownership found in other studies may be attributed to the greater residential stability of the neighborhood where homeowners live. It is the better neighborhoods and school experienced by children of homeowners that account for their better outcomes.

In contrast to Green and White, and Aaronson, Haurin et al (2002) focus on the cognitive and behavioral outcomes of 1000 young children, age five to eight rather than 17 -year old teenagers using the National longitudinal Survey of Youth (NLSY79) and the NLSY Child data. They show that for children living in owned home, mathematical cognitive outcome is higher, reading recognition score is higher, and children's behavior problems are lower, holding constant a large number of social, demographic and economic variables.

\subsection{Improved Financial Returns through Homeownership}

The importance of the homeownership to the individual and society is widely acknowledged. It has become important to consider ownership of a home as an 
investment for which the home owners will receive attractive and positive financial returns. The financial returns from residential housing take the form of income and capital growth.

Hutchison (1994) examines whether home owning can be considered a good investment in the short to medium term, both in absolute term and in comparison with shares for the period of 1984 to 1992 . The housing data used in this study are extracted from the Inland Revenue Property Market Report and 50 main towns and cities in six regions in the United Kingdom are selected. The share return data are taken from the Barclays de Zoete Wedd (BZW) Equity-Glit Study. The results have shown that the returns from housing exceed the rise in the Retail Price Index but fall below the return from shares. This is in line with risk/ return theory where it is considered that a rational investor will require different levels of return depending on the risk profile of the investment.

In addition to the capital and income growth of home owning, residential housing is proved to be an investment instrument to hedge against inflation as compare to other assets. An early study on housing inflation hedging ability is by Fama and Schwert (1977). They compare U.S. government bonds and bills, private residential real estate and common stocks in terms of their ability to hedge against Treasury bill rates, as a measure of expected and unexpected movement in inflation in the $1953-1971$ periods. The regression results show that expected changes in both government bonds and bill and private housing property rates of return are close to unity with respect to a $1 \%$ change in expected inflation rate, common stock returns are negatively related to expected changes 
in inflation rate, and private housing property has positive and significant of 1.19 and 0.56 relationship in both expected and unexpected inflation rate respectively. They conclude that real estate is the only complete hedge against expected and unexpected inflation in the sample period.

\subsection{Determinants of Homeownership Externalities}

The basic relationship between homeownership and externalities is well established. However, these studies do not explain why homeowners are motivated to provide a better home environment for their children, to improve neighborhood stability and to invest in housing. As such, determinants behind externalities of homeownership need to be examined.

There are few studies in housing literature that examined determinants of homeownership externalities. Glaeser and Sacerdote (2000) contribute to literatures on the neighborhood stability through homeownership by stating housing structure (either single-family detached dwelling or multi-unit dwelling) is an important determinant of local amenity investment and social connection using U.S. General Social Service (GSS) and German Socio-Economic Panel (GSOEP) data sets. From both surveys in the United States and Germany, they show that homeowners of single-family detached dwelling make better citizens by involving in local and national election, solving local problems, and gardening whereas residents of multi-unit dwelling are less likely to vote in local election, are less likely to solve local problem, and are less likely to garden. 
Determinants related to externalities of homeownership also often help to explain discrepancies in homeownership rates, why some individuals are more likely to own their properties as compare to others. There are well-established tenure choice determinants literatures, which have developed over the past two decades. Many researchers have developed tenure choice models and found varying assortment of the determinants to be significant to the tenure choice decision ranging from social, political, legal, culture to economic variables. All studies found that the decision to own is associated with household income, wealth, family size, marital status, race, and the age of the head of household. Previous studies also show that the relative cost of owning has found to affect home purchase decision (Goodman 1990; Haurin and Kamara 1992; Laakso and Loikkanen 1995; Bourassa 1995; Coulson 1999; Maki 2001; Fisher and Jaffe 2003; Gwin and Ong 2004).

\subsection{Research Questions}

In modeling the relationship between outcome measures of homeownership and determinants, the research question is to assess whether socio-cultural, economic and housing determinants exhibit statistically significant differences and associations for externalities of homeownership collectively and individually. 
Figure 1:

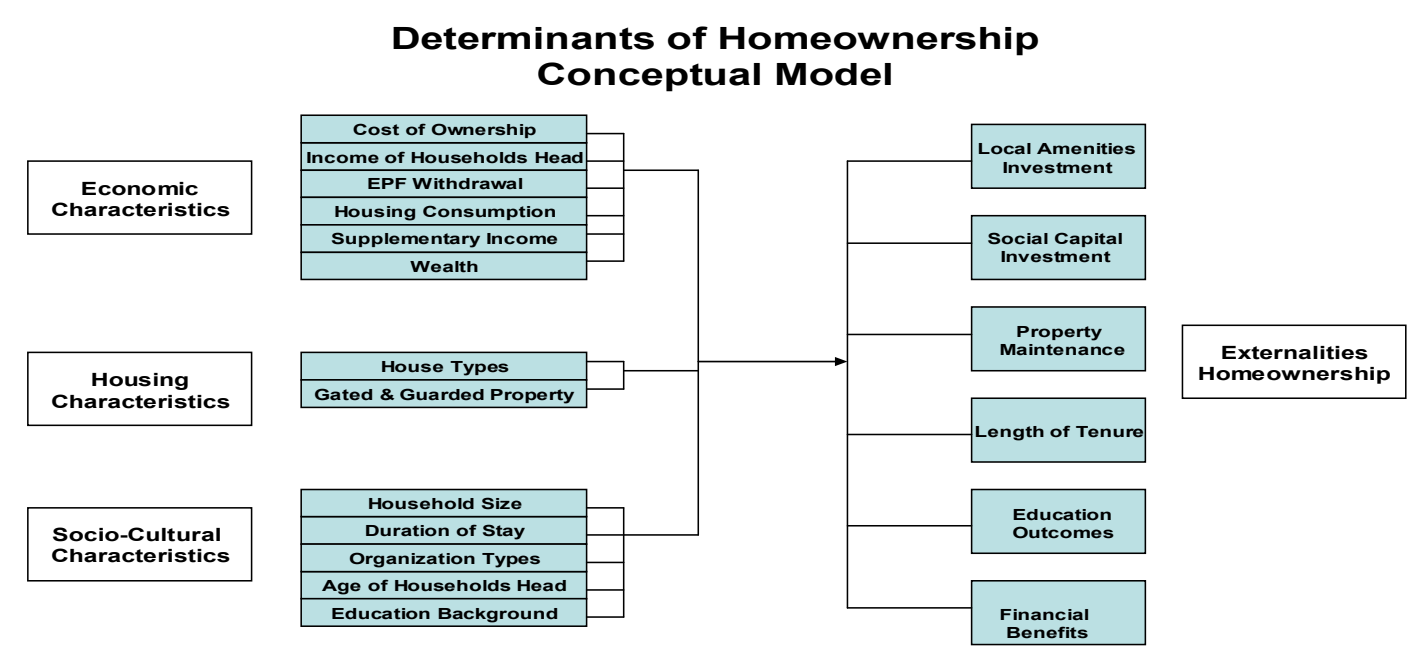

\subsection{Methodology}

In this study, the researcher conducts the Factor Analysis to measure constructs with multiple indicator variables of homeownership using Principal Component Extraction Method. Once factors have been extracted, the research uses oblique (promax) rotation because oblique rotation theoretically renders a more accurate solution and yields simple and more interpretable factor patterns. The researcher generally expects some correlation among factors since behavior functions dependently of one another. Factors will be used as constructs of externalities of homeownership, which are associated with local amenities, property maintenance and improvement, tenure length, children education outcome, social capital investment and financial benefits of homeownership.

Once the dependent variables are identified, GLM multivariate statistical procedure is performed to provide insights into not only the predictive power of the independent 
measures but also the interrelationships and differences seen in the set of dependent measures. In addition to multivariate statistical testing, univariate statistical test is used to examine each externality of homeownership separately for differences across all categorical and covariate determinants.

\subsection{Variables used in the study}

The dependent variables of homeownership used in all previous housing studies only consist of a single indicator variable. In this paper, the homeownership variable is a subset of 25-itme deriving outcome measures of homeownership. Respondents in the survey are asked as to how agreeable they are with motivations of home owning. Responses are scored on a five-point scale ranging from 1 for "strongly disagreed", 2 for "disagreed", 3 for "neutral", 4 for "agreed" and 5 for "strongly agreed". All questions used in the survey derive from several housing studies of Rohe and Steward (1996), Rossi and Weber (1996), Green and White (1997), DiPasquale and Glaeser (1999), Evan et al (2000) and Haurin et al (2002).

In this study, several independent variables which may cause differences in how respondents view about community, family and financial benefits of homeownership are identified. These include housing characteristics (house types and property types), socialcultural and economic descriptors (age, occupation, education attainment, and types of organization in which the householders attach to). Besides, some relationships are expected between externalities of homeownership with number of EPF withdrawal, 
duration of stay in the present house, monthly housing consumption, family size, supplementary income, wealth and price of owning.

\subsection{Sampling}

The researcher chooses to sample a cross section of householders. The respondents who are eligible for answering the questionnaire are householders in Malaysia. According to Population and Housing Census of Malaysia (2000), there are 4.9 million householders in Malaysia. The sample of householders is randomly selected in a series of step. First, the area sample, the most popular type of cluster sample, is used to sample economically while retaining the characteristics of a probability sample. In this study, the researcher only focused on householders from 2 main states - Kuala Lumpur state and Selangor state. These two states contributed more than $45 \%$ of the total amount of constructed residential units in the country. Also, the total number of householders in these two states accounted for $31 \%$ in the country, which were 926, 747 householders in Selangor and 305, 154 householders in Kuala Lumpur (Population and Housing Census of Malaysia, 2000). Second, the researcher chose districts within the states to ensure that the different areas are represented in the sample. In this case, 4 districts each were identified in two states, namely Gombak, Klang, Petaling, and Hulu Langat in Selangor state and Kepong, Cheras, K.L city and Wangsa Maju in Kuala Lumpur state. As a final step, 50 householders within each district were chosen and interviewed by using convenience sampling. In total, 400 householders were interviewed. The interview and survey were conducted in identified residential areas nearer to major hypermarkets in each district. 


\subsection{Analysis}

\subsection{Measurement Assessment of Externalities of Homeownership}

The Promax rotation has sorted 17 questionnaire questions into 6 factors. The first and second factors explain 18 percent and 14 percent of the total variance respectively. The third factor only accounts for 11 percent of the total variance. The last three factors only accounts for 8 percent, 7 percent and 6 percent of total variance respectively. Of all six factors, 62 percent of the total variance is reported.

Factor 1 is associated with local amenities investment. In line with the findings of William and Leslie (1996), Rossi and Weber (1996) and DiPasquale and Glaeser (1999), Malaysian homeowners believe homeownership improves the neighborhood stability through higher participation in local neighborhood organizations. Participation in local organizations is able to give homeowners capacity to ward off outside and inside threats in the community. These activities, in turn, are though to lead more stable neighborhoods which will benefit homeowners both economically and socially. As seen in Table 1 (see Appendix A), the Cronbach's alpha value of this construct is 0.77 , which suggesting that the intercorrelation of question 11,13 and 14 measure the same thing.

In the survey, Malaysian householders agree that homeownership increases the economic stability of neighborhood as they are more likely to maintain their properties at a higher standard. Factor 2, which refers to as properties maintenance and improvement of homeownership, consist of the question 23, question 24, and question 25 with factor 
loadings of $0.814,0.764$, and 0.613 respectively. The Cronbach's alpha value of this construct is reasonably high, which is 0.66 . As William and Leslie (1996) point out that the economic stability of the neighborhood will increase only if homeowners improve and maintain their properties well. The reasons of such improvement are that they are interested in economic interest (wealth accumulation and capital appreciation) and use interest (enjoyment, satisfaction and non-economic benefits) of owing properties.

Factor 3 comprises survey items regarding improved neighborhood stability through longer commitment to stay in the community. As expected, Malaysian householders choose to become homeowners only if they are prepared to stay in the neighborhood for a long time. In this survey, question 20, question 18 and question 19 have factor loadings of $0.756,0.737$, and 0.656 respectively. Again, the Cronbach's alpha value is greater than 0.67 , which suggesting that these 3 questions are one-dimensional and may be combined in a scale.

Malaysian householders also believe that children's education outcome will improve and behavior problem will reduce if the children live in owned home. In line with the findings of Green and White (1997), they are more likely to monitor their own children and their neighbors' children as bad behavior of children either homeowners own or their neighbors may reduce the attractiveness of the neighborhood and threaten the value of homes. Factor 5 consists of the question 10, question 9 and question 5 with factor loading of $0.801,0.721$, and 0.570 respectively and the Cronbach's alpha value of these 3 questions is 0.61 . 
The greater commitment that Malaysian householders have toward their neighborhood show clearly itself in greater socialization with neighborhood in the community. In this survey, Factor 5, which is defined as the social links among neighbors, has the Cronbach's alpha value of 0.64 .

Finally, Factor 6 consists of items relating to improved financial benefits through homeownership. In line with the literature review, Malaysian householders believe that they will receive financial returns in the form of income and capital growth through home owning. Home owning is proved to be an investment instrument to accumulate wealth as property values tend to appreciate over a longer period of time.

\subsection{Multivariate Statistical Analysis (MANCOVA)}

This section presents results of the partial effect of each determinant on community, family and financial benefits of homeownership, controlling for the effects of covariate variables that are generally present with homeownership. Normality and equal variance assumptions are assessed and satisfied before multivariate statistical testing can be performed.

As shown in Table 2 MANCOVA results (see Appendix B), motivations and views on outcome measures of homeownership are statistically significant different for householders who live in different house types and property types, who work in different organization types and who are at the different stages of their life cycle. In addition, motivations of homeownership change when the educational level and the income level 
change. Of all covariate variables, the effect of EFP withdrawal, duration of stay in the present house, monthly housing expenditure, household size, supplementary income in the family, wealth of the household head and relative price of owning are all statistically significant related to externalities of homeownership.

\subsection{Univariate Statistical Testing}

The next analysis is to examine each externality of homeownership separately for differences and relationships across social-cultural, economic and demographic descriptors suing univariate statistical testing.

The results in Table 3a (see Appendix B) reveals that all other thing being equal, house type is only statistically significant differ from the children education outcome of homeownership with a power of $86 \%$. Results in Table $3 \mathrm{~b}$ reveal that homeowners of terrace houses in the survey are motivated to own homes because they expect homeownership will impact the child's cognitive ability. However, the results show that house types is statistically insignificant differ from local amenities investment of homeownership. This finding is not in line with the works of Glaeser and Sacerdote (2000). They explain that owners of detached houses are motivated to see local amenities and act politically to correct externalities created by neighbors because their house structures are physically nearer to local services and they have more connection to surrounding local public services and actions of neighbors. Owners of high rise apartments, on the other hand, are negatively related to working to solve local problem as they are most separated from the political issues that surround them. Holding all other 
factors constant, none of the house types is significant differ from social capital investment of homeownership. Again, this contrasts the finding in Glaeser and Sacerdote's model that residents of high rise apartments are more likely to be socially connected with their neighbors as compare to detached house residents because they are physically more proximate to their neighbors. Reduction in physical distance between neighbors in high rise apartments could drive up social interaction between neighbors. They usually use common space to socialize with someone from the neighborhood. The study also does not support the hypotheses that the differences in house types are statistically significant differ from longer community tenure, property maintenance and improvement and financial benefits of homeownership, if all other variables remain constant.

The influence of property types shows statistically significant effect on children education outcomes $(p=0.006$, power $82.4 \%)$ and social capital investment $(p=0.028$, power $67 \%$ ) of homeownership. According to the survey, owners who live in non-gated but guarded community are motivated to monitor their own children and socialize more with their neighbors. It is reasonable to believe that frequent interaction with neighbors within guarded community may keep homeowner up to date not only on the behavior of their own children but also their neighbors' children. In addition, owning a home will increase owners' self-esteem and life satisfaction. An increased parental self-esteem will result in a greater emotional support for their children. The greater emotional supports will lead to better cognitive outcomes and few behavior problems. However, the study does not support the hypotheses that there are differences in property types on local 
amenities investment, property maintenance and improvement, length of tenure and financial benefits of homeownership when control for all covariate variables.

Among the individual and household socio-demographic characteristics, age only shows significant effects on financial benefits of homeownership, all other thing being equal. In this survey, respondents who are in the less than 35 age group are motivated to consider ownership of a home as an investment for attractive and positive financial returns. There is no difference in the age of householders on local amenities investment, children education outcomes, property maintenance and improvement, tenure length, and social capital investment of homeownership. It is surprising to learn that householders who are more than 45 years old in the survey, where careers tend to be more established, have low valence on the above mentioned externalities of homeownership.

The results in Table 6a (see Appendix B) show that the level of education attainment of the head of household is only less pronounced for the improvement of children education outcomes of homeownership. The influences of education appear to be statistically significant differ from local amenities investment $(\mathrm{p}=0.002$, power $90 \%$ ), property maintenance and improvement $(p=0.001$, power $93 \%)$, length of tenure $(p=0.007$, power $82 \%)$, social capital investment $(\mathrm{p}=0.016$, power $74 \%)$ and financial benefits of home owning $(\mathrm{p}=0.001$, power $95 \%$ ). Householders with secondary education background are motivated to participate in local community organization by holding leadership and activist position and improve social link among neighbors as compare to other education groups. As for property maintenance and improvement, tenure length and financial 
benefits of homeownership, the highest mean score are reported for householders with tertiary education background. These results are consistent with those obtained by DiPasquale and Glaeser (1999) and Glaeser and Sacerdote (2000).

The abundant studies that have employed the homeownership models tend to indicate that income appears to be a significant determinant to explain the changes in outcome measures of homeownership. Out of six outcome variables of homeownership, the effects of income are statistically significant differ from local amenities investment $(p=0.000$, power $97 \%)$, tenure length $(\mathrm{p}=0.000$, power $100 \%)$, children education outcome $(0.009$, power $80 \%$ ) and social capital investment ( $\mathrm{p}=0.007$, power $82 \%$ ) of homeownership. The results show that householders who earned less than RM 4,000 per month in the survey are motivated to contribute money, time and effort to local improvement group. This is supported by the fact that incentives to invest in local amenities are higher only when householders are less likely to be planning a move due to lower income. Higher income, on the other hand, influences the mobility of householders as higher income clearly widens the likelihood of moving into bigger and better houses. As for child education outcome of homeownership, the highest mean score is reported for householders who earn between RM 4,000 and RM 8,000, which indicating that they have high valence on children cognitive ability and behavior problem. According to the survey, they also show deep commitment and great satisfaction with the community in the neighborhood. In terms of social capital investment of homeownership, they are more likely to be socially connected with their neighbors. However, no significance difference found in the 
monthly income of householders on property maintenance and improvement and financial benefits of homeownership when control for all covariate variables.

Not many housing studies have specifically investigated the type of organization in which householders are employed on outcome measures of homeownership. The estimation from the survey show that, holding all other factors constant, organization types are statistically significant differ from local amenities investment $(\mathrm{p}=0.038$, power $62 \%$ ), tenure length $(0.01$, power $78 \%)$, children education outcome $(p=0.001$, power $92 \%)$ and financial benefits $(0.011$, power $77 \%)$ of homeownership. With respect to the means of type of organization in which the households head are employed, the results indicate that households head from publicly owned organization are motivated to improve the quality of the neighborhood by holding leading position in the local community organization and consider ownership of a home as an investment tool for wealth accumulation. It is reasonable to believe that householders from publicly owned organization are more likely to invest in local amenities as their working hours are fixed and predictable. As a result, they have more time for their own activities such as joining local improvement groups. Higher involvement in local politics, in fact, may increase the attractiveness of the neighborhood which may cause higher appreciation of the home value. As for householders who work in other than private and public sectors such as self-employed and non-for-profit organizations are more likely to show deep commitment to stay in the community longer and believe a positive relationship exist being raised in an owned home and education outcomes for the children of homeowners. However, there is no 
difference in the types of organization in which householders are employed on property maintenance and improvement and social capital investment of homeownership.

Employee Provident Fund (EPF) withdrawal might be seen as a symbolic act announcing that a household is committed to remaining in a community for a long time. Presumably, householders with higher number of EPF withdrawal often stay in their homes longer $(\mathrm{p}=0.028$, power $59 \%)$. Householders with EFP withdrawal tend to believe that homeownership will improve child education outcomes ( $p=0.003$, power $84 \%$ ). Results also suggest that householders who choose to withdraw funds from EPF account are more likely to increase the attractiveness of their neighborhood by creating neighborhood networks which may increase the capital and income growths of their homes $(p=0.000$, power 93\%). Positive significant relationships are reported on local amenities investment, social capital investment and property maintenance and improvement of homeownership for homeowners who made EPF withdrawal for home financing, but these relationship are insignificant.

Of all outcome variables, only local amenities investment and social capital investment of homeownership are significantly and positively related to the duration of stay. Householders who live in the present house longer are committed to improve social link among neighbors $(\mathrm{p}=0.018$, power $66 \%$ ). The length of duration that homeowners stay in the present house also explains some of relationships in the local amenities investment $(p=0.022$, power $63 \%)$. These results are consistent with the findings of William and Leslie (1996), DiPasquale and Glaeser (1999) and Glaeser and Sacerdote (2000) as 
participation in local improvement organizations will increase only if householders stay in the current house longer. However, there are no significant associations between the duration of stay in the present house and property maintenance and improvement, tenure length, child outcomes, and financial benefits of homeownership if all other variables remain constant.

The parameter estimates of monthly housing consumption on externalities of homeownership are inconclusive, with most of externalities of homeownership being statistically insignificant. Monthly housing expenditure is only significantly $(\mathrm{p}=0.000$, power $95 \%$ ) and negatively related to length of tenure of homeownership, indicating householders who spend large portion of monthly income on housing consumption are less likely to stay in one home longer. Negative relationships are also reported in local amenities investment, property maintenance and improvement, children education outcomes, social capital investment and financial benefits of homeownership, but the associations are not statistically significant.

Everything else being equal, the household size is significantly and positively associated length of tenure $(p=0.001$, power $93 \%)$ and social capital investment $(p=0.000$, power $100 \%$ ) of homeownership. These results suggest that householders with more dependents are less likely to move again as tangible and intangible costs of relocation are relatively higher. As for social capital investment of homeownership, householders with more dependents may interact with their neighbors frequently to monitor their children. However, the relationships with household size are insignificant include local amenities 
investment, property maintenance and improvement, children education outcomes and financial benefits of homeownership, assuming all other variables remain constant.

The estimation results show that, holding all other factors constant, higher supplementary income in the family increases the mobility of householders which has resulted in shorter community tenure in the neighborhood $(\mathrm{p}=0.018$, power $66 \%$ ). Again, householders with more sources of income may contribute money, time and efforts to local improvement groups $(\mathrm{p}=0.003$, power $85 \%)$. The supplementary income in the family may appear to have a significant role on children education outcome of homeownership $(p=0.034$, power $57 \%$ ). Householders with working dependents may socialize less $(\mathrm{p}=0.003$, power $86 \%)$ with neighbors because they rather spend more time with their children in the families which may lead them to center their sociability less outside of their families. Property maintenance and financial benefits of homeownership, on the other hand, are insignificantly related to the supplementary income in the family.

The study shows householders facing less liquidity constraints often stay longer in their homes $(\mathrm{p}=0.05$, power $50 \%$ ) which may cause them to hold leadership and activist positions in local improvement groups to invest in local public goods for the improvement of the quality of the neighborhood ( $\mathrm{p}=0.001$, power $91 \%$ ) as well as to monitor their children closely $(\mathrm{p}=0.039$, power $54 \%$ ). The liquidity constraint, on the other hand, is not significantly related to property maintenance and improvement, social capital investment and financial benefits of homeownership. 
The relative price of the owning is relevant to the homeownership decisions. However, to date, no empirical work has been conducted to investigate the relationship between the relative price of owning and externalities of homeownership. Out of six outcome variables of homeownership, the effects of the relative price of owning are significantly and positively related to tenure length $(\mathrm{p}=0.003$, power $85 \%)$, children education outcome $(p=0.015$, power $69 \%)$ and financial benefits of homeownership $(p=0.022$, power 63\%). As expected, householders show deep commitment to stay longer in the neighborhood because transaction costs associated with homeownership are relatively high. They become owners only when they are reasonably sure that they would not have to pay them again for a long time. They also have a stronger incentive to monitor their own children as well as their neighbors' children. As mentioned earlier, bad behavior of children either homeowner own or their neighbors may reduce the attractiveness of the neighborhood and threaten the value of homes which may lead to a lower property value appreciation over a longer period of time. However, the study does not support the hypotheses that there are significant associations in the relative price of owning on local amenities investment, property maintenance and improvement, and social capital investment of homeownership.

\subsection{Conclusion and Recommendation}

Public policy that encourages homeownership has often been justified by claims that it has a variety of benefits both to both individual and to society. Given these benefits, there is justification for policies makers that encourage homeownership. It is important to 
know determinants behind externalities of homeownership as householders general differ in background and motivations of home owning. The main objective of this paper is to tackle property oversupply in the country by examining a detailed knowledge of home owning determinants. Homeownership is a complex issue that is the result of many determinants, including housing characteristics of householders (house types and property types, and patterns of socio-cultural, economic and demographic.

\section{Recommendation for Property Oversupply}

\section{Efforts needed to provide housing for all in the target area must be accompanied by investment in infrastructure and employment opportunities.}

In order to address the property overhang in Malaysia, housing policy makers are required to understand a detailed knowledge of home owning determinants. Housing market is fragmented according to complex matrices that reflect different ages, household characteristics, income levels and housing preferences. Housing products have to be precisely targeted according to complex matrices. As a result, housing policy makers and housing developers are required to carry out research to ascertain market needs as a lot of housing projects were started without proper plans. As indicated earlier, the majority of unsold houses are situated in poor location with no adequate amenities and facilities and less employment opportunities. Efforts needed to provide housing in the target area must be accompanied by investment in infrastructure and employment opportunities. Based on experiences from Singapore, the Housing Development Board (HDB) provides quality self-contained housings within a functional and landscaped residential development 
where householders can find the place within the new residential township to work, shop, school, and fulfill recreational needs.

\section{Efforts needed to reduce regulatory barriers in the housing delivery system that can significantly increase the costs of producing housing}

The government should formulate policies aimed at reducing costs of housing and improving the efficiency of housing delivery system in the country. Changes have been made recently to revamp the country's public delivery system to slash bureaucracy and consequently the cost of doing business in the property sector. These changes streamline all processes prior to construction concerning land, planning and building plan approval. A newly drawn up work-flow chart details working processes with a time frame spelt out for the action to be taken by each and every technical department involved in the approval-issuing process. Apart from reformatted and simplified application procedures, a One-Stop-Centre (OTC) has been set up to speed up the process in handling and approving housing projects, replacing the Certification of Fitness for Occupation (CFO) with the Certification of Completion and Compliance (CCC) and incentives for developers to adopt the Build Then Sell (BTS) concept. Clearly such initiatives will result in greater efficiency and transparency in the housing industry. But it is not enough that the government works at bringing about the changes, it must be seen to be doing so. Words must be translated to action and speedily. To ensure that the time line is adhered to, an agency is required to set up at the Ministry of Housing and Local Government to monitor progress as well as to receive complaints. Again, it is not just setting time lines, nor is it about a mere elimination of work duplication by technical departments. It is 
about a concerted attempt to expel from the system unhealthy practices that has been long established and practices that have given rise to complaints of corruption.

\section{Efforts have been made to extend opportunities to mortgages so that householders can own their own homes.}

Homeownership required affordable housing financing. Mortgage lending has to reconcile affordability to borrowers and viability to lenders. The policy and programs developed are those attempting to cheapen the cost of homeownership through financial assistance with down payment and mortgage interest payments. The government should also increase the availability of alternative home financing by liberalizing EPF savings for down payment and mortgage payment. As shown in research, EPF withdrawal seems to be an important role in promoting externalities of homeownership. As such, rules and regulation of EPF withdrawal, particularly documentation needed for the submission of EPF withdrawal, need to be simplified in order to enhance the efficiency of the withdrawal system. Also, a better EPF withdrawal information system is required to integrate land office in every states and financial institutions as well as EPF department for the simplification of withdrawal system.

\section{References}

Aaronson, D., A Note on the Benefits of Homeownership, Journal of Urban Economics. 47 (2000) 356 369.

Bourassa, S.C., A Model of Housing Tenure Choice in Australia, Journal of Urban Economics, 37 (1995) $161-175$.

Coulson, N.E., Why Are Hispanic- and Asian-American Homeownership Rates So Low? Immigration and Other Factors, Journal of Urban Economics. 45 (1999) 209 - 227. 
Department of Statistics Malaysia. Population and Housing Census of Malaysia., Kuala Lumpur, 2000.

DiPasquale, D., and Glaeser., E.L, Incentives and Social Capital: Are Homeowners Better Citizens? Journal of Urban Economics. 45 (1999) 354 - 384.

Fama, E.F., and Schwert, G. W., Asset Returns and Inflation, Journal of Financial Economics. 5 (1997) $115-164$

Fisher, L.M., and Jaffe, A.J., Determinants of International Home Ownership Rates, Housing Finance International. 18, 1 (2003) $34-42$.

Green, R K., and White, M, J., Measuring the Benefits of Homeowning: Effects on Children, Journal of Urban Economics. 41 (1997) 441 - 461.

Glaeser, Edward L., and Sacerdote, B., The Social Consequences of Housing, Journal of Housing Economics. 9 (2000) 1 - 23.

Goodman, A.C., Demographics of Individual Housing Demand, Regional Science and Urban Economics. 20 (1990) 83 -102 .

Gwin, C.R., and Ong, S.E., Do We Really Understand Homeownership Rates? An International Study, Working Paper Series, Baylor University.

Hair, J.H., Anderson, R.E., Tatham, R.L., and Black, W.C., Multivariate Data Analysis, fifth edition. Prentice Hall International. New Jersey, 1998.

Haurin, D. R., and Kamara D., The Homeownership Decision of Female-Headed Households, Journal of Housing Economics. 2, 4 (1993) 293 - 309.

Haurin, D. R., Parcel, T. L., and Haurin, R. J., Does Homeownership Affect Child Outcomes? Real Estate Economics. 30, 4 (2002) $635-666$

Hutchison, N.E., Housing as an Investment? A Comparison of Returns from Housing with Other Types of Investment, Journal of Property Finance, 5, 2 (1994) 47 - 61.

Laakso, S., and Loikkanen, H.A., (1995). "Finnish Homes - Through Passages or Traps?" Real Estate Economics. 23, 4: 475 - 495.

Maki, A., Liquidity Constraints: A Cross-Sectional Analysis of the Housing Purchasing Behavior of Japanese Households, The Review of Economics and Statistics. 75, 3 (1993) 429 - 437.

Rohe, W.M., and Stewart L.S., Homeownership and Neighborhood Stability, Housing Policy Debate. 7, 1 (1996) $37-81$

Rossi, P.H., and Weber, E., The Social Benefits of Homeownership: Empirical Evidence from National Survey, Housing Policy Debates. 7 (1996) $1-35$.

Vroom, Victor. H., Work and Motivations. John Wiley and Sons. New York, 1964. 
Appendix A

Table 1: Factor Loading of the Effects of Homeownership (Questionnaire Variables Used as Outcome Measures)

\begin{tabular}{|c|c|c|c|c|c|c|}
\hline Items & 1 & 2 & 3 & 4 & 5 & 6 \\
\hline \multicolumn{7}{|l|}{ Local Amenities Investment } \\
\hline $\begin{array}{l}\text { I have worked to solve local community problems in the } \\
\text { neighborhood (Q.11) }\end{array}$ & 0.776 & & & & & \\
\hline $\begin{array}{l}\text { I am a committee member of local improvement group } \\
\text { (residential association, religious organizations or union) in my } \\
\text { neighborhood (Q.13) }\end{array}$ & 0.769 & & & & & \\
\hline $\begin{array}{l}\text { I contributed money, time and efforts to local improvement } \\
\text { group in my neighborhood (Q.14) }\end{array}$ & 0.739 & & & & & \\
\hline \multicolumn{7}{|l|}{ Property Maintenance in the Neighborhood } \\
\hline $\begin{array}{l}\text { I have an incentive to maintain my current dwelling unit well } \\
\text { (Q.23) }\end{array}$ & & 0.814 & & & & \\
\hline $\begin{array}{l}\text { All homeowners benefit from enhancement in their dwelling } \\
\text { units if the improvements bring them added enjoyment in the } \\
\text { neighborhood (Q.24) }\end{array}$ & & 0.764 & & & & \\
\hline $\begin{array}{l}\text { All homeowners benefit from enhancement in their dwelling } \\
\text { units if the improvement increase the value of property in the } \\
\text { neighborhood (Q.25) }\end{array}$ & & 0.613 & & & & \\
\hline \multicolumn{7}{|l|}{ Length of Tenure } \\
\hline $\begin{array}{l}\text { I like to stay longer in the neighborhood as I am satisfied with the } \\
\text { community (Q.20) }\end{array}$ & & & 0.756 & & & \\
\hline I have a deeper commitment to stay in my community (Q.18) & & & 0.737 & & & \\
\hline $\begin{array}{l}\text { I like to stay longer as I am satisfied with environments in my } \\
\text { community (Q.19) }\end{array}$ & & & 0.656 & & & \\
\hline \multicolumn{7}{|l|}{ Children Cognitive Ability and Behavior Problems } \\
\hline $\begin{array}{l}\text { Children raised in owned home are more likely to have fewer } \\
\text { behavior problems (Q.10) }\end{array}$ & & & & 0.801 & & \\
\hline $\begin{array}{l}\text { Homeownership will improve the academic results of children in } \\
\text { school (Q.9) }\end{array}$ & & & & 0.721 & & \\
\hline $\begin{array}{l}\text { I have a stronger incentive to monitor my own children and } \\
\text { neighbors' children (Q.5) }\end{array}$ & & & & 0.570 & & \\
\hline \multicolumn{7}{|l|}{ Social Capital Investment } \\
\hline $\begin{array}{l}\text { I always socialize in public space outside of my home with } \\
\text { friends and neighbors (Q.22) }\end{array}$ & & & & & 0.843 & \\
\hline $\begin{array}{l}\text { I always spend an evening out with someone from the } \\
\text { neighborhood (Q.21) }\end{array}$ & & & & & 0.801 & \\
\hline \multicolumn{7}{|l|}{ Financial Benefits of Home Owning } \\
\hline Residential property has the potential for income growth (Q.2) & & & & & & 0.756 \\
\hline $\begin{array}{l}\text { I enjoyed capital appreciation of more than } 30 \% \text { from my } \\
\text { residential property (Q.1) }\end{array}$ & & & & & & 0.710 \\
\hline Residential property has the potential for capital growth (Q.3) & & & & & & 0.553 \\
\hline Eigenvalues & 3.189 & 2.489 & 1.920 & 1.405 & 1.222 & 1.012 \\
\hline$\%$ of Variance Explained & 17.715 & 13.829 & 10.666 & 7.807 & 6.789 & 5.623 \\
\hline Cumulative \% of Variance Explained & 17.715 & 31.544 & 42.210 & 50.017 & 56.805 & 62.429 \\
\hline Cronbach's Alpha & 0.7654 & 0.6640 & 0.6716 & 0.6091 & 0.6420 & 0.4529 \\
\hline Scale Mean & 2.8669 & 3.7808 & 3.3914 & 3.6116 & 2.6607 & 4.0771 \\
\hline Scale Variance & 0.0005 & 0.0652 & 0.0189 & 0.0357 & 0.0003 & 0.1091 \\
\hline
\end{tabular}


Appendix B

Table 2: MANCOVA

\begin{tabular}{|c|c|c|c|c|c|c|c|}
\hline Effect & $\begin{array}{c}\text { Wilks' } \\
\text { Lambda } \\
\text { Value }\end{array}$ & $\mathbf{F}$ & Hypothesis df & Error df & Sig. & $\begin{array}{l}\text { Noncent. } \\
\text { Parameter }\end{array}$ & $\begin{array}{c}\text { Observed } \\
\text { Power }\end{array}$ \\
\hline Intercept & .948 & 2.844 & 6.000 & 308.000 & .010 & 17.066 & .886 \\
\hline Age & .909 & 2.514 & 12.000 & 616.000 & .003 & 30.166 & .975 \\
\hline Education & .796 & 6.203 & 12.000 & 616.000 & .000 & 74.437 & 1.000 \\
\hline Property types & .918 & 2.230 & 12.000 & 616.000 & .009 & 26.764 & .954 \\
\hline EPF withdrawal & .919 & 4.544 & 6.000 & 308.000 & .000 & 27.265 & .986 \\
\hline Years of stay & .955 & 2.442 & 6.000 & 308.000 & .025 & 14.653 & .824 \\
\hline Housing consumption & .951 & 2.637 & 6.000 & 308.000 & .017 & 15.819 & .857 \\
\hline Family size & .917 & 4.672 & 6.000 & 308.000 & .000 & 28.033 & .989 \\
\hline Supplementary income & .903 & 5.491 & 6.000 & 308.000 & .000 & 32.948 & .996 \\
\hline
\end{tabular}

Table 3 House Types on Homeownership

a. Tests of Between Subject Effect

\begin{tabular}{|l|r|r|r|r|r|r|}
\hline Dependent Variable & \multicolumn{1}{|c|}{$\begin{array}{c}\text { Sum of } \\
\text { Squares }\end{array}$} & \multicolumn{1}{c|}{ df } & Mean Square & \multicolumn{1}{c|}{ F } & \multicolumn{1}{c|}{$\begin{array}{c}\text { Observed } \\
\text { Power }\end{array}$} \\
\hline Local Amenities Investment & .909 & 2 & .455 & .538 & .584 & .139 \\
\hline Property Maintenance and Improvement & 3.029 & 2 & 1.515 & 1.611 & .201 & .340 \\
\hline Length of Tenure & .734 & 2 & .367 & .450 & .638 & .123 \\
\hline $\begin{array}{l}\text { Children Cognitive Ability \& Behavior } \\
\text { Problems }\end{array}$ & 9.022 & 2 & 4.511 & 5.639 & .004 & .858 \\
\hline Social Capital Investment & .863 & 2 & .431 & .506 & .603 & .133 \\
\hline Financial Benefits & 2.166 & 2 & 1.083 & 1.331 & .266 & .287 \\
\hline
\end{tabular}

\section{b. Means}

\begin{tabular}{|c|c|c|c|c|c|}
\hline \multirow[b]{2}{*}{ Dependent Variable } & \multirow[b]{2}{*}{ House type } & \multirow[b]{2}{*}{ Mean } & \multirow[b]{2}{*}{ Std. Error } & \multicolumn{2}{|c|}{ 95\% Confidence Interval } \\
\hline & & & & Lower Bound & Upper Bound \\
\hline \multirow[t]{2}{*}{ Local Amenities Investment } & High rise & -.007 & .109 & -.223 & .208 \\
\hline & Semi-detached and detached & -.195 & .138 & -.466 & .076 \\
\hline \multirow{2}{*}{$\begin{array}{l}\text { Property Maintenance and } \\
\text { Improvement }\end{array}$} & High rise & .144 & .115 & -.083 & .371 \\
\hline & Terrace & -.123 & .098 & -.316 & .069 \\
\hline \multirow{2}{*}{ Length of Tenure } & Terrace & -.031 & .091 & -.210 & .148 \\
\hline & Semi-detached and detached & .097 & .135 & -.169 & .363 \\
\hline \multirow{3}{*}{$\begin{array}{l}\text { Children Cognitive Ability } \\
\& \text { Behavior Problems }\end{array}$} & High rise & -.265 & .107 & -.475 & -.056 \\
\hline & Terrace & .198 & .090 & .021 & .375 \\
\hline & Semi-detached and detached & .088 & .134 & -.175 & .352 \\
\hline \multirow{2}{*}{ Financial Benefits } & Terrace & -.070 & .091 & -.248 & .109 \\
\hline & Semi-detached and detached & .205 & .135 & -.061 & .470 \\
\hline
\end{tabular}

\section{Table 4 Property Types on Homeownership}

a. Tests of Between Subject Effect
\begin{tabular}{|l|r|r|r|r|r|r|}
\hline Dependent Variable & $\begin{array}{c}\text { Sum of } \\
\text { Squares }\end{array}$ & \multicolumn{1}{|c|}{ df } & Mean Square & \multicolumn{1}{c|}{ F } & \multicolumn{1}{c|}{$\begin{array}{c}\text { Sig. } \\
\text { Observed } \\
\text { Power }\end{array}$} \\
\hline Local Amenities Investment & 4.791 & 2 & 2.395 & 2.835 & .060 & .554 \\
\hline Property Maintenance and Improvement & 3.119 & 2 & 1.560 & 1.658 & .192 & .349 \\
\hline Length of Tenure & .909 & 2 & .454 & .557 & .574 & .142 \\
\hline Children Cognitive Ability \& Behavior & 8.258 & 2 & 4.129 & 5.162 & .006 & .824 \\
\hline
\end{tabular}




\begin{tabular}{|l|r|r|r|r|r|r|}
\hline Problems & & & & & & \\
\hline Social Capital Investment & 6.174 & 2 & 3.087 & 3.621 & .028 & .667 \\
\hline Financial Benefits & .516 & 2 & .258 & .317 & .729 & .100 \\
\hline
\end{tabular}

\begin{tabular}{|c|c|c|c|c|c|}
\hline \multirow[b]{2}{*}{ Dependent Variable } & \multirow[b]{2}{*}{ Gated and guarded property } & \multirow[b]{2}{*}{ Mean } & \multirow[b]{2}{*}{ Std. Error } & \multicolumn{2}{|c|}{ 95\% Confidence Interval } \\
\hline & & & & Lower Bound & Upper Bound \\
\hline \multirow[t]{3}{*}{ Local Amenities Investment } & gated and guarded properties & -.277 & .104 & -.482 & -.071 \\
\hline & non-gated but guarded properties & .044 & .107 & -.167 & .254 \\
\hline & $\begin{array}{l}\text { non-gated and non-guarded } \\
\text { properties }\end{array}$ & .011 & .101 & -.189 & .210 \\
\hline \multirow{3}{*}{$\begin{array}{l}\text { Property Maintenance and } \\
\text { Improvement }\end{array}$} & gated and guarded properties & -.003 & .110 & -.220 & .213 \\
\hline & non-gated but guarded properties & -.156 & .113 & -.378 & .066 \\
\hline & $\begin{array}{l}\text { non-gated and non-guarded } \\
\text { properties }\end{array}$ & .144 & .107 & -.066 & .354 \\
\hline \multirow[t]{3}{*}{ Length of Tenure } & gated and guarded properties & .005 & .102 & -.197 & .206 \\
\hline & non-gated but guarded properties & .065 & .105 & -.142 & .272 \\
\hline & $\begin{array}{l}\text { non-gated and non-guarded } \\
\text { properties }\end{array}$ & -.099 & .100 & -.294 & .097 \\
\hline \multirow{3}{*}{$\begin{array}{l}\text { Children Cognitive Ability \& } \\
\text { Behavior Problems }\end{array}$} & gated and guarded properties & -.133 & .101 & -.332 & .067 \\
\hline & non-gated but guarded properties & .268 & .104 & .064 & .473 \\
\hline & $\begin{array}{l}\text { non-gated and non-guarded } \\
\text { properties }\end{array}$ & -.115 & .099 & -.309 & .079 \\
\hline \multirow[t]{3}{*}{ Social Capital Investment } & gated and guarded properties & -.169 & .105 & -.375 & .037 \\
\hline & non-gated but guarded properties & .205 & .107 & -.006 & .417 \\
\hline & $\begin{array}{l}\text { non-gated and non-guarded } \\
\text { properties }\end{array}$ & -.064 & .102 & -.264 & .136 \\
\hline \multirow[t]{3}{*}{ Financial Benefits } & gated and guarded properties & .031 & .102 & -.170 & .233 \\
\hline & non-gated but guarded properties & -.005 & .105 & -.212 & .201 \\
\hline & $\begin{array}{l}\text { non-gated and non-guarded } \\
\text { properties }\end{array}$ & .118 & .099 & -.078 & .313 \\
\hline
\end{tabular}

Table 5 Households Head Age on Homeownership

a. Tests of Between Subject Effect
\begin{tabular}{|l|r|r|r|r|r|r|}
\hline Dependent Variable & Sum of Squares & \multicolumn{1}{c|}{ df } & \multicolumn{1}{c|}{$\begin{array}{c}\text { Mean } \\
\text { Square }\end{array}$} & \multicolumn{1}{c|}{ F } & \multicolumn{1}{c|}{$\begin{array}{c}\text { Observed } \\
\text { Sig. }\end{array}$} \\
\hline Local Amenities Investment & 4.877 & 2 & 2.438 & 2.886 & .057 & .562 \\
\hline $\begin{array}{l}\text { Property Maintenance and } \\
\text { Improvement }\end{array}$ & 1.694 & 2 & .847 & .900 & .407 & .205 \\
\hline Length of Tenure & 3.201 & 2 & 1.600 & 1.961 & .142 & .405 \\
\hline $\begin{array}{l}\text { Children Cognitive Ability \& } \\
\text { Behavior Problems }\end{array}$ & 2.896 & 2 & 1.488 & 1.810 & .165 & .377 \\
\hline Social Capital Investment & 3.384 & 2 & 1.692 & 1.984 & .139 & .011 \\
\hline Financial Benefits & 7.442 & 2 & 3.721 & 4.573 & .011 \\
\hline
\end{tabular}

\begin{tabular}{|c|c|c|c|c|c|}
\hline \multirow[b]{2}{*}{ Dependent Variable } & \multirow{2}{*}{$\begin{array}{l}\text { Age of the head of } \\
\text { household }\end{array}$} & \multirow[b]{2}{*}{ Mean } & \multirow[b]{2}{*}{ Std. Error } & \multicolumn{2}{|c|}{ 95\% Confidence Interval } \\
\hline & & & & Lower Bound & Upper Bound \\
\hline \multirow{3}{*}{$\begin{array}{l}\text { Local Amenities } \\
\text { Investment }\end{array}$} & less than 35 & .143 & .112 & -.077 & .364 \\
\hline & $35-45$ & -.208 & .098 & -.400 & -.016 \\
\hline & more than 45 & -.158 & .110 & -.374 & .058 \\
\hline \multirow{3}{*}{$\begin{array}{l}\text { Property Maintenance and } \\
\text { Improvement }\end{array}$} & less than 35 & -.047 & .118 & -.279 & .185 \\
\hline & $35-45$ & .109 & .103 & -.093 & .312 \\
\hline & more than 45 & -.078 & .116 & -.305 & .150 \\
\hline \multirow[t]{3}{*}{ Length of Tenure } & less than 35 & .010 & .110 & -.207 & .226 \\
\hline & $35-45$ & .128 & .096 & -.061 & .317 \\
\hline & more than 45 & -.166 & .108 & -.379 & .046 \\
\hline \multirow{3}{*}{$\begin{array}{l}\text { Children Cognitive Ability } \\
\text { \& Behavior Problems }\end{array}$} & less than 35 & .124 & .109 & -.090 & .338 \\
\hline & $35-45$ & .071 & .095 & -.116 & .259 \\
\hline & more than 45 & -.175 & .107 & -.385 & .036 \\
\hline \multirow[t]{3}{*}{ Social Capital Investment } & less than 35 & .175 & .112 & -.046 & .396 \\
\hline & $35-45$ & -.115 & .098 & -.308 & .078 \\
\hline & more than 45 & -.088 & .110 & -.305 & .129 \\
\hline
\end{tabular}




\begin{tabular}{|l|r|r|r|r|}
\hline less than 35 & .328 & .110 & .112 & .544 \\
\hline $35-45$ & -.090 & .096 & -.279 & .098 \\
\hline more than 45 & -.094 & .108 & -.306 & .118 \\
\hline
\end{tabular}

Table 6 Education Background of the Householder on Homeownership a. Tests of Between Subject Effect

\begin{tabular}{|l|r|r|r|r|r|r|}
\hline $\begin{array}{l}\text { Dependent Variable } \\
\text { Local Amenities Investment }\end{array}$ & \multicolumn{1}{c|}{ Sum of Squares } & \multicolumn{1}{c|}{$\begin{array}{c}\text { Mean } \\
\text { Square }\end{array}$} & \multicolumn{1}{c|}{ F } & \multicolumn{1}{c|}{$\begin{array}{c}\text { Observed } \\
\text { Power }\end{array}$} \\
\hline $\begin{array}{l}\text { Property Maintenance and } \\
\text { Improvement }\end{array}$ & 10.933 & 2 & 5.466 & 6.470 & .002 & .904 \\
\hline Length of Tenure & 13.581 & 2 & 6.791 & 7.221 & .001 & .933 \\
\hline $\begin{array}{l}\text { Children Cognitive Ability \& } \\
\text { Behavior Problems }\end{array}$ & 8.271 & 2 & 4.135 & 5.068 & .007 & .817 \\
\hline Social Capital Investment & 1.288 & 2 & .644 & .805 & .448 & .187 \\
\hline Financial Benefits & 7.171 & 2 & 3.585 & 4.205 & .016 & .736 \\
\hline
\end{tabular}

\begin{tabular}{|c|c|c|c|c|c|}
\hline \multirow[b]{2}{*}{ Dependent Variable } & \multirow[b]{2}{*}{ Education } & \multirow[b]{2}{*}{ Mean } & \multirow[b]{2}{*}{ Std. Error } & \multicolumn{2}{|c|}{$\mathbf{9 5 \%}$ Confidence Interval } \\
\hline & & & & Lower Bound & Upper Bound \\
\hline \multirow{3}{*}{$\begin{array}{l}\text { Local Amenities } \\
\text { Investment }\end{array}$} & primary & -.061 & .098 & -.255 & .132 \\
\hline & secondary & .165 & .088 & -.008 & .338 \\
\hline & tertiary & -.326 & .101 & -.524 & -.128 \\
\hline \multirow{3}{*}{$\begin{array}{l}\text { Property Maintenance } \\
\text { and Improvement }\end{array}$} & primary & -.305 & .104 & -.510 & -.101 \\
\hline & secondary & .022 & .093 & -.161 & .204 \\
\hline & tertiary & .269 & .106 & .060 & .478 \\
\hline \multirow[t]{3}{*}{ Length of Tenure } & primary & -.173 & .097 & -.364 & .017 \\
\hline & secondary & -.104 & .087 & -.274 & .067 \\
\hline & tertiary & .248 & .099 & .054 & .443 \\
\hline \multirow{3}{*}{$\begin{array}{l}\text { Children Cognitive } \\
\text { Ability \& Behavior } \\
\text { Problems }\end{array}$} & primary & -.030 & .096 & -.219 & .159 \\
\hline & secondary & .100 & .086 & -.069 & .269 \\
\hline & tertiary & -.049 & .098 & -.242 & .144 \\
\hline \multirow{3}{*}{$\begin{array}{l}\text { Social Capital } \\
\text { Investment }\end{array}$} & primary & .074 & .099 & -.120 & .269 \\
\hline & secondary & .142 & .088 & -.033 & .316 \\
\hline & tertiary & -.244 & .101 & -.443 & -.045 \\
\hline \multirow[t]{3}{*}{ Financial Benefits } & primary & .174 & .097 & -.016 & .364 \\
\hline & secondary & -.242 & .086 & -.412 & -.072 \\
\hline & tertiary & .212 & .099 & .017 & .406 \\
\hline
\end{tabular}

Table 7: Household Head Income on Homeownership

a. Tests of Between Subject Effect

\begin{tabular}{|l|r|r|r|r|r|r|}
\hline Dependent Variable & Sum of Squares & df & \multicolumn{1}{c|}{$\begin{array}{c}\text { Mean } \\
\text { Square }\end{array}$} & \multicolumn{1}{|c|}{$\begin{array}{c}\text { Observed } \\
\text { Power }\end{array}$} & \multicolumn{1}{c|}{ Sig. } \\
\hline Local Amenities Investment & 14.919 & 2 & 7.459 & 8.829 & .000 & .971 \\
\hline $\begin{array}{l}\text { Property Maintenance and } \\
\text { Improvement }\end{array}$ & 2.797 & 2 & 1.398 & 1.487 & .228 & .316 \\
\hline Length of Tenure & 31.360 & 2 & 15.680 & 19.217 & .000 & 1.000 \\
\hline $\begin{array}{l}\text { Children Cognitive Ability \& } \\
\text { Behavior Problems }\end{array}$ & 7.668 & 2 & 3.834 & 4.793 & .009 & .794 \\
\hline Social Capital Investment & 8.628 & 2 & 4.314 & 5.060 & .007 & .316 \\
\hline Financial Benefits & 2.271 & 2 & 1.135 & 1.395 & .249 & .29 \\
\hline
\end{tabular}

b. Means

\begin{tabular}{|c|c|c|c|c|c|}
\hline \multirow[b]{2}{*}{ Dependent Variable } & \multirow[b]{2}{*}{ Income } & \multirow[b]{2}{*}{ Mean } & \multirow[b]{2}{*}{ Std. Error } & \multicolumn{2}{|c|}{$\mathbf{9 5 \%}$ Confidence Interval } \\
\hline & & & & Lower Bound & Upper Bound \\
\hline \multirow{3}{*}{ Local Amenities Investment } & less than 4000 & .221 & .102 & .020 & .423 \\
\hline & $4000-8000$ & .062 & .090 & -.116 & .240 \\
\hline & more than 8000 & -.506 & .124 & -.750 & -.262 \\
\hline \multirow{3}{*}{$\begin{array}{l}\text { Property Maintenance and } \\
\text { Improvement }\end{array}$} & less than 4000 & .077 & .108 & -.135 & .290 \\
\hline & $4000-8000$ & -.138 & .095 & -.326 & .049 \\
\hline & more than 8000 & .046 & .131 & -.212 & .304 \\
\hline
\end{tabular}




\begin{tabular}{|c|c|c|c|c|c|}
\hline \multirow[t]{3}{*}{ Length of Tenure } & less than 4000 & .189 & .101 & -.009 & .387 \\
\hline & $4000-8000$ & .352 & .089 & .178 & .527 \\
\hline & more than 8000 & -.570 & .122 & -.810 & -.330 \\
\hline \multirow{2}{*}{$\begin{array}{l}\text { Children Cognitive Ability } \\
\& \text { Behavior Problems }\end{array}$} & less than 4000 & .028 & .100 & -.168 & .224 \\
\hline & more than 8000 & -.223 & .121 & -.460 & .015 \\
\hline \multirow[t]{2}{*}{ Social Capital Investment } & less than 4000 & .098 & .103 & -.104 & .301 \\
\hline & $4000-8000$ & .179 & .091 & $1.262 \mathrm{E}-05$ & .357 \\
\hline \multirow[t]{3}{*}{ Financial Benefits } & less than 4000 & -.110 & .100 & -.308 & .087 \\
\hline & $4000-8000$ & .083 & .089 & -.091 & .258 \\
\hline & more than 8000 & .170 & .122 & -.069 & .410 \\
\hline
\end{tabular}

Table 8: Organization Types on Homeownership

a. Tests of Between Subject Effect
\begin{tabular}{|l|r|r|r|r|r|r|}
\hline Dependent Variable & $\begin{array}{c}\text { Sum of } \\
\text { Squares }\end{array}$ & df & Mean Square & \multicolumn{1}{c|}{ F } & $\begin{array}{c}\text { Observed } \\
\text { Power }\end{array}$ \\
\hline Local Amenities Investment & 5.587 & 2 & 2.794 & 3.307 & .038 & .624 \\
\hline $\begin{array}{l}\text { Property Maintenance and } \\
\text { Improvement }\end{array}$ & 1.726 & 2 & .863 & .918 & .400 & .208 \\
\hline Length of Tenure & 7.618 & 2 & 3.809 & 4.668 & .010 & .783 \\
\hline $\begin{array}{l}\text { Children Cognitive Ability \& } \\
\text { Behavior Problems }\end{array}$ & 10.807 & 2 & 5.403 & 6.754 & .001 & .916 \\
\hline Social Capital Investment & 3.539 & 2 & 1.770 & 2.076 & .127 & .426 \\
\hline Financial Benefits & 7.390 & 2 & 3.695 & 4.541 & .011 & .770 \\
\hline
\end{tabular}

\begin{tabular}{|c|c|c|c|c|c|}
\hline \multirow[b]{2}{*}{ Dependent Variable } & \multirow[b]{2}{*}{ Organization } & \multirow[b]{2}{*}{ Mean } & \multirow[b]{2}{*}{ Std. Error } & \multicolumn{2}{|c|}{ 95\% Confidence Interval } \\
\hline & & & & Lower Bound & Upper Bound \\
\hline \multirow{3}{*}{$\begin{array}{l}\text { Local Amenities } \\
\text { Investment }\end{array}$} & public sector & .139 & .097 & -.052 & .329 \\
\hline & private sector & -.188 & .092 & -.369 & -.006 \\
\hline & others & -.173 & .101 & -.371 & .024 \\
\hline \multirow{3}{*}{$\begin{array}{l}\text { Property Maintenance and } \\
\text { Improvement }\end{array}$} & public sector & -.120 & .102 & -.321 & .081 \\
\hline & private sector & .030 & .097 & -.162 & .222 \\
\hline & others & .074 & .106 & -.134 & .283 \\
\hline \multirow[t]{3}{*}{ Length of Tenure } & public sector & -.256 & .095 & -.444 & -.069 \\
\hline & private sector & .093 & .091 & -.086 & .272 \\
\hline & others & .135 & .099 & -.060 & .329 \\
\hline \multirow{3}{*}{$\begin{array}{l}\text { Children Cognitive } \\
\text { Ability \& Behavior } \\
\text { Problems }\end{array}$} & public sector & .132 & .094 & -.054 & .317 \\
\hline & private sector & -.276 & .090 & -.453 & -.099 \\
\hline & others & .166 & .098 & -.027 & .358 \\
\hline \multirow[t]{3}{*}{ Social Capital Investment } & public sector & -.154 & .097 & -.345 & .038 \\
\hline & private sector & -.007 & .093 & -.189 & .176 \\
\hline & others & .133 & .101 & -.066 & .331 \\
\hline \multirow[t]{3}{*}{ Financial Benefits } & public sector & .288 & .095 & .100 & .475 \\
\hline & private sector & -.117 & .091 & -.295 & .062 \\
\hline & others & -.027 & .099 & -.222 & .167 \\
\hline
\end{tabular}

Table 9

\begin{tabular}{|c|c|c|c|c|c|c|}
\hline & Dependent Variable & B & $\begin{array}{c}\text { Std. } \\
\text { Error }\end{array}$ & $\mathbf{t}$ & Sig. & $\begin{array}{c}\text { Observed } \\
\text { Power }\end{array}$ \\
\hline \multirow[t]{6}{*}{ EPF } & Local Amenities & .119 & .073 & 1.627 & .105 & .368 \\
\hline & Property Maintenance & .002 & .077 & .023 & .981 & .050 \\
\hline & Tenure length & .158 & .072 & 2.203 & .028 & .593 \\
\hline & Children Education & .212 & .071 & 2.980 & .003 & .844 \\
\hline & Social Capital & .065 & .073 & .880 & .380 & .142 \\
\hline & Financial Benefits & .257 & .072 & 3.577 & .000 & .946 \\
\hline Duration & Local Amenities & .021 & .009 & 2.301 & .022 & .631 \\
\hline \multirow[t]{5}{*}{ of stay } & Property Maintenance & .008 & .010 & .781 & .435 & .122 \\
\hline & Tenure length & .010 & .009 & 1.075 & .283 & .188 \\
\hline & Children Education & .009 & .009 & 1.006 & .315 & .171 \\
\hline & Social Capital & .022 & .009 & 2.388 & .018 & .663 \\
\hline & Financial Benefits & -.006 & .009 & -.699 & .485 & .107 \\
\hline
\end{tabular}




\begin{tabular}{|c|c|c|c|c|c|c|}
\hline Monthly & Local amenities & -.003 & .006 & -.586 & .558 & .090 \\
\hline housing & Property maintenance & -.007 & .006 & -1.159 & .247 & .211 \\
\hline \multirow[t]{4}{*}{ consumption } & Tenure length & -.020 & .006 & -3.642 & .000 & .953 \\
\hline & Children education & -.010 & .006 & -1.801 & .073 & .435 \\
\hline & Social capital & -.007 & .006 & -1.230 & .220 & .232 \\
\hline & Financial benefits & -.008 & .006 & -1.375 & .170 & .278 \\
\hline Household & Local amenities & .032 & .037 & .847 & .398 & .135 \\
\hline \multirow[t]{5}{*}{ size } & Property maintenance & .016 & .039 & .395 & .693 & .068 \\
\hline & Tenure length & .126 & .037 & 3.442 & .001 & .929 \\
\hline & Children education & .023 & .036 & .630 & .529 & .096 \\
\hline & Social capital & .176 & .037 & 4.717 & .000 & .997 \\
\hline & Financial benefits & -.020 & .037 & -.540 & .590 & .084 \\
\hline Supplementary & Local amenities & .189 & .063 & 2.989 & .003 & .846 \\
\hline \multirow[t]{5}{*}{ income } & Property maintenance & .094 & .067 & 1.404 & .161 & .288 \\
\hline & Tenure length & -.147 & .062 & -2.372 & .018 & .657 \\
\hline & Children education & .131 & .062 & 2.134 & .034 & .567 \\
\hline & Social capital & -.193 & .064 & -3.040 & .003 & .858 \\
\hline & Financial benefits & .046 & .062 & .744 & .457 & .115 \\
\hline \multirow[t]{6}{*}{ Wealth effect } & Local amenities & .636 & .194 & 3.284 & .001 & .906 \\
\hline & Property maintenance and improvement & -.068 & .204 & -.332 & .740 & .063 \\
\hline & Tenure length & .375 & .190 & 1.969 & .050 & .501 \\
\hline & Children education & .392 & .189 & 2.078 & .039 & .544 \\
\hline & Social capital & .323 & .195 & 1.661 & .098 & .381 \\
\hline & Financial benefits & .074 & .190 & .391 & .696 & .068 \\
\hline \multirow[t]{6}{*}{ Price owning } & Local amenities & .269 & .180 & 1.493 & .136 & .319 \\
\hline & Property maintenance & .149 & .190 & .784 & .434 & .122 \\
\hline & Tenure length & .533 & .177 & 3.008 & .003 & .851 \\
\hline & Children education & .431 & .176 & 2.456 & .015 & .687 \\
\hline & Social capital & -.177 & .181 & -.975 & .330 & .163 \\
\hline & Financial benefits & .406 & .177 & 2.294 & .022 & .628 \\
\hline
\end{tabular}


Appendix C

25 questions (outcome measure of homeownership)

\begin{tabular}{|c|c|}
\hline Q1 & I enjoyed capital appreciation of more than $30 \%$ from my residential property \\
\hline Q2 & Residential property has the potential for income growth \\
\hline Q3 & Residential property has the potential for capital growth \\
\hline Q4 & Home owing is not only as a basic need for living but also a major source of wealth \\
\hline Q5 & I have a stronger incentive to monitor my own children and neighbors' children \\
\hline Q6 & I agree children of homeowners stay in school longer than children of renters \\
\hline Q7 & I think children are the greatest joy in life \\
\hline Q8 & The level of home environment for children will be improved if I am a home owner \\
\hline Q9 & Homeownership will improve the academic results (PMR, SPM, STPM) of my children in school \\
\hline Q10 & Children raised in owned home are more likely to have fewer behavior problems \\
\hline Q11 & I have worked to solve local community problems in the neighborhood \\
\hline Q12 & I enjoy gardening at home \\
\hline Q13 & $\begin{array}{l}\text { I am a committee member of local improvement group (residential association, religious organizations or union) in my } \\
\text { neighborhood }\end{array}$ \\
\hline Q14 & I contributed money, time and efforts to local improvement group in my neighborhood \\
\hline Q15 & I know local enforcement officials in my neighborhood \\
\hline Q16 & I know the name of the parliament members in my state and district \\
\hline Q17 & I vote in local election \\
\hline Q18 & I have a deeper commitment to stay in my community \\
\hline Q19 & I like to stay longer as I am satisfied with environments in my community \\
\hline Q20 & I like to stay longer in the neighborhood as I am satisfied with the community \\
\hline Q21 & I always spend an evening out with someone from the neighborhood \\
\hline Q22 & I always socialize in public space outside of my home with friends and neighbors \\
\hline Q23 & I have an incentive to maintain my current dwelling unit well \\
\hline Q24 & $\begin{array}{l}\text { All homeowners benefit from enhancement in their dwelling units if the improvements bring them added enjoyment in the } \\
\text { neighborhood }\end{array}$ \\
\hline Q25 & $\begin{array}{l}\text { All homeowners benefit from enhancement in their dwelling units if the improvement increase the value of property in the } \\
\text { neighborhood }\end{array}$ \\
\hline
\end{tabular}

